\title{
Analisis Kemampuan Komunikasi Matematis Siswa Lamban Belajar dalam Menyelesaikan Soal Bangun Datar
}

\author{
Nanang Supriadi ${ }^{1}$, Rani Damayanti ${ }^{2}$ \\ 1,2IAIN Raden Intan Lampung: nanangsupriadi@gmail.com
}

Submitted : 15-04-2016, Revised : 25-04-2016, Accepted : 16-06-2016

\begin{abstract}
The purpose of this study is to find out how mathematical communication ability of students slow in learning to solve the problem of waking flat in SD Negeri 1 Sukamaju Abung semuli north Lampung. The research method used is descriptive research using qualitative approach. The result of the research can be concluded is that the students write communication is slower to learn better than oral communication, it can be seen from the result of the answer of the student who answer the correct bigger than the student answer that correct answer in oral communication. It is said that students are slow to learn to have limitations to talk or convey ideas so they are more silent or even just smiling.
\end{abstract}

Keywords: Communication; Mathematical; Slow Learner.

\begin{abstract}
Abstrak
Tujuan penelitian ini adalah untuk mengetahui bagaimanakah kemampuan komunikasi matematis siswa lamban belajar dalam menyelesaikan soal bangun datar di SD Negeri 1 Sukamaju Abung semuli Lampung utara. Metode penelitian yang digunakan adalah penelitian deskriptif dengan menggunakan pendekatan kualitatif. Hasil penelitian yang dapat disimpulkan adalah, komunikasi tulis siswa lamban belajar lebih baik dibandingkan komunikasi lisan, ini terlihat dari hasil jawaban siswa yang menjawab benar lebih besar dibandingkan jawaban siswa yang menjawab benar dalam komunikasi lisan. Hal ini dikarnakan siswa lamban belajar memiliki keterbatasan untuk berbicara atau menyampaikan ide sehingga mereka lebih banyak diam atau bahkan hanya tersenyum.
\end{abstract}

Kata Kunci : Komunikasi; Matematis; Slow Learner.

\section{PENDAHULUAN}

Pendidikan mempunyai peranan penting dalam kehidupan sehari-hari. Di dalam Undang-Undang juga dijelaskan bahwa setiap penduduk berhak mendapatkan pendidikan yang bermutu (Sisdiknas, Sistem Pendidikan Nasional, 2010). Akan tetapi pendidikan yang selama ini sering kita dengar dan sering dibahas selalu tentang pendidikan siswa yang normal, semestinya pendidikan tidak hanya diperuntukkan bagi siswa yang normal saja, tetapi ada pula anak berkebutuhan khusus yang seharusnya mereka perlu untuk diberikan perhatian yang lebih dalam hal pendidikan serta mereka juga memiliki hak yang sama untuk memperoleh pengajaran dan bergaul dengan sesamanya tanpa memandang adanya keterbatasan atau diskriminasi. Anak berkebutuhan khusus adalah anak yang memiliki 
karakteristik yang berbeda dengan anak- anak normal lainya, baik dilihat dari segi emosi, mental maupun secara fisiknya.

Anak yang tergolong dalam anak berkebutuhan khusus salah satunya yaitu siswa lamban belajar (slow learner). Siswa lamban belajar adalah siswa yang memiliki prestasi belajar rendah atau sedikit di bawah rata-rata dari anak normal pada umumnya, baik pada salah satu atau seluruh area akademik. Jika dilakukan pengetesan pada IQ, skor tes IQ menunjukkan skor antara 70 dan 90. Siswa yang tergolong dalam anak lamban belajar memiliki karakteristik sebagai berikut: (1) dari segi intelegensi anak-anak lamban belajar berada pada kisaran di bawah rata-rata yaitu 70-90 berdasarkan skala WISC. (2) dari segi bahasa anak lamban belajar mengalami masalah dalam berkomunikasi baik dalam bahasa ekspresif atau menyampaikan ide. (3) dalam hal emosi anak- anak yang lamban belajar memiliki emosi yang kurang stabil serta sensitif. (4) anak lamban belajar dalam bersosialisasi biasanya kurang baik mereka cenderung pasif (Triani, 2013).

Berdasarkan data hasil nilai ulangan siswa diperoleh bahwa hasil nilai ulangan siswa lamban belajar berada di bawah kriteria ketuntasan minimal yaitu <60. Masalah yang dihadapi siswa lamban belajar adalah dari segi komunikasi, baik komunikasi secara lisan maupun tulisan. Pembelajaran matematika sulit dikomunikasikan karna terbentur dengan simbol-simbol yang bersifat abstrak (Supriadi, 2017). Banyak dari siswa lamban belajar yang mengalami kesulitan dari segi pengucapan/lisan serta tulisan. Seperti yang terjadi di dalam kelas siswa tidak dapat mengucapkan kembali apa yang diucapkan oleh guru, mereka cenderung hanya mengikuti teman-temannya yang dianggap bisa. Sedangkan dalam hal komunikasi tulis siswa tidak dapat menulis dengan benar bahkan ada siswa yang tidak mau menulis sama sekali, hal ini yang mengakibatkan kemampuan komunikasi siswa lamban belajar tergolong belum lancar.

Lemahnya kemampuan komunikasi matematis siswa lamban belajar mengakibatkan kemampuan mereka dalam menyelesaikan soal akan lemah pula. Kegiatan yang paling penting dalam pembelajaran matematika adalah menyelesaikan permasalahan secara matematis, khususnya masalah yang akan ditemui dalam kehidupan sehari- hari.

\section{METODE PENELITIAN}

Jenis penelitian ini merupakan penelitian deskriptif dengan pendekatan kualitatif. Penelitian deskriptif adalah penelitian untuk mendeskripsikan suatu gejala, peristiwa dan kejadian yang terjadi dengan memusatkan perhatian pada masalah-masalah aktual sebagaimana adanya ketika penelitian berlangsung tanpa memberikan perlakuan khusus terhadap peristiwa. Hubungan penelitian deskriptif dengan pendekatan kualitatif karena menggambarkan kegiatan penelitian yang dilakukan pada obyek tertentu secara jelas dan sistematis, dengan melakukan eksplorasi guna menerangkan dan memprediksi suatu gejala yang terjadi atas dasar data kualitatif yang diperoleh di lapangan.

Teknik pengambilan sample yang digunakan peneliti adalah teknik purposive sampling (Sugiono, 2009). Teknik ini dipilih dengan tujuan dan alasan tertentu berdasarkan penelitian yang diambil. Partisipan yang akan diwawancarai dan diamati dalam penelitian ini dipilih karna mereka adalah orang-orang yang terlibat secara langsung dengan penelitian yang diteliti di sekolah tersebut. Subjek yang dipilih dalam penelitian ini sebnyak 5 orang siswa kelas V SD Negeri 1 Sukamaju Abung semuli Lampung Utara. Instrumen penelitian ini 
berbentuk tes dan wawancara, instrumen tes digunakan untuk mengukur kemampuan komunikasi tulis siswa lamban belajar (slow learner) sedangkan wawancara digunakan untuk mengukur kemampuan komunikasi lisan siswa lamban belajar. Soal tes kemampuan komunikasi matematis siswa berupa soal uraian yang terdiri dari 3 soal sedangkan untuk kemampuan komunikasi lisan menggunakan pedoman wawancara dengan kisi-kisi wawancara sebanyak 11 pertanyaan. Hasil lembar jawaban siswa akan dianalisis dengan menggunkan rubrik tingkat komunikasi tulis sedangkan hasil wawancara siswa akan dianalisis dengan menggunkan rubrik tingkat komunikasi lisan. Dengan tingkatan 5 untuk jawaban siswa yang menjawab lengkap dan benar, 4 untuk jawaban siswa yang menjawab hampir lengkap dan benar, 3 untuk jawaban siswa yang menjawab sebagian benar, 2 untuk jawaban siswa yang menjawab dengan prosedur samar dan 1 untuk jawaban siswa yang menjawab tidak rinci dan tidak menunjukkan proses solusi.

\section{HASIL PENELITIAN DAN PEMBAHASAN}

Deskripsi Kemampuan Komunikasi Matematis Tulis Siswa Lamban Belajar

Salah satu contoh hasil tes tulis siswa subjek pertama SD Negeri 1 Sukamaju dalam menyelesaikan masalah matematika diantaranya adalah:

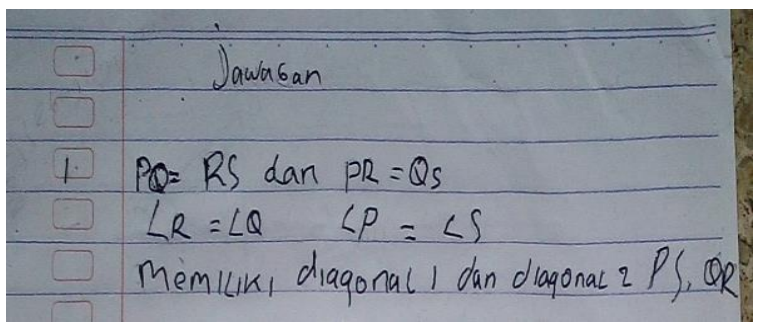

Gambar 1. Hasil Tes Tulis Siswa Lamban Belajar Subjek Pertama

Dari data tertulis yang disajikan pada gambar diperoleh:

a. Penjelasan tentang proses penyelesaian masalah yang ditulis jelas dan benar.

b. Mengubah masalah ke kalimat matematika benar

c. Penggunaan simbol atau tanda matematika benar

Berdasarkan uraian analisis data di atas dan dikaitkan dengan rubrik tingkat komunikasi tulis maka dapat disimpulkan bahwa subjek pertama tersebut menempati tingkat 5 dengan kategori lengkap dan benar

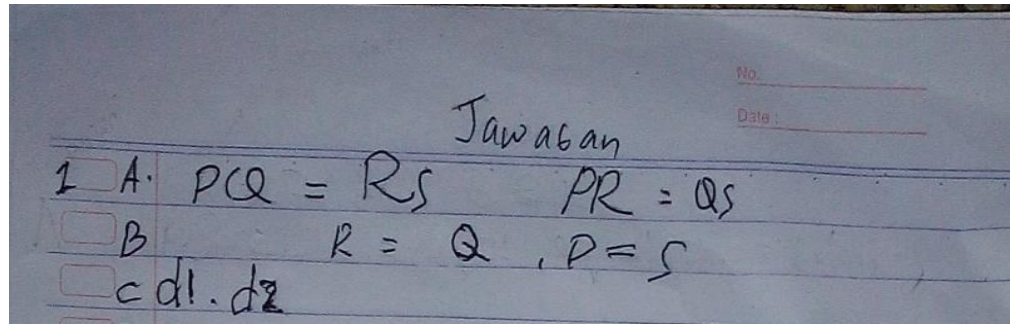

Gambar 2. Hasil Tes Tulis Siswa Lamban Belajar Subjek Kedua

Dari data tertulis yang disajikan pada gambar diperoleh:

a. Penjelasan tentang proses penyelesaian masalah yang ditulis jelas dan benar.

b. Mengubah masalah ke kalimat matematika benar 
c. Penggunaan simbol atau tanda terdapat kekurangan penulisan

Berdasarkan uraian analisis data di atas dan dikaitkan dengan rubrik tingkat komunikasi tulis maka dapat disimpulkan bahwa subjek kedua menempati tingkat 4 dengan kategori hampir lengkap dan benar. Deskripsi hasil komunikasi tulis siswa lamban belajar yang diperoleh dari ketiga butir soal tersebut dapat ditulis ke dalam bentuk persentase seperti pada tabel dibawah ini:

Tabel 1. Persentasi Hasil Analisis Kemampuan Komunikasi Tulis Siswa

\begin{tabular}{cccccccccccccccc}
\hline \multicolumn{11}{c}{ PPM (\%) } & \multicolumn{11}{c}{ MKM (\%) } & \multicolumn{1}{c}{ PH (\%) } & \multicolumn{4}{c}{ SBMT (\%) } \\
\hline JB & B & SB & HBK & T & B & SB & TT & JB & SK & K & SB & TB & B & KP & S \\
& & & T & & & & & & & & & & \\
\hline 6, & 2 & 13, & 33,3 & 2 & 33 & 13, & 53, & 6 & 40 & 13, & 0 & 40 & 6, & 60 & 33 \\
6 & 6 & 3 & & 0 & 3 & 3 & 3 & 6 & & 3 & & & 6 & \\
\hline
\end{tabular}

Berdasarkan Tabel 3 di atas data yang diperoleh analisis kemampuan komunikasi tulis siswa untuk proses penyelesaian masalah (PPM) Siswa yang menjawab dengan jelas dan benar (JB) sebesar 6,6 \%. Siswa yang menjawab tidak tepat (TT) sebesar $20 \%$. Siswa yang menjawab hanya bebapa konsep saja sebesar 33, 3\% dari indikator pencapaian yang telah ditetapkan yaitu $60 \%$. Dilihat dari analisis data yang diperoleh ini menunjukkan bahwa siswa sudah hampir mampu menyelesaikan masalah dengan benar meskipun hanya beberapa konsep saja hal ini terlihat dari persentasi siswa yang menjawab sebagian konsep (HBK) lebih besar dari pada siswa yang menjawab tidak tepat (TT).

Untuk penyelesaian masalah yang diubah kekalimat matematika (MKM) siswa yang menjawab benar (B) hanya sebesar 33,3\%, sedangkan siswa yang menjawab tidak tepat (TT) lebih tinggi persentasinya yaitu sebesar $53,3 \%$ dari data yang diperoleh terlihat bahwa siswa dalam mengubah masalah ke dalam kalimat matematika (MKM) masih sangat kurang ini terlihat dari persentasi jawaban siswa yang tidak tepat (TT) lebih tinggi dibanding siswa yang menjawab dengan benar.

Selain itu untuk perhitungan (PH) siswa yang menjawab dengan jelas dan benar (JB) hanya sebesar $6, .6 \%$ sedangkan siswa yang menjawab tidak benar (TB) sebesar $40 \%$. Hal ini menunjukkan bahwa untuk perhitungan persentasi siswa yang menjawab tidak benar lebih tinggi dibandingkan siswa yang menjawab dengan benar (B), artinya dalam perhitungan ( $\mathrm{PH})$ siswa lamban belajar masih banyak kesalahan.

Dilihat dari simbol matematika (SBMT) siswa yang menjawab dengan jelas dan benar (JB) sebesar 6,6\% untuk siswa yang menjawab salah (S) sebesar 33,3\% sedangkan siswa yang menjawab dengan sedikit kesalahan (kekurangan penulisan /KP) sebesar 60\%. Dari data yang diperoleh menunjukkan untuk penyelesaian simbol matematika siswa sudah mencapai indikator yang ditentukan, ini terlihat dari persentasi siswa yang menjawab simbol matematika dengan sedikit kekurangan sebesar $60 \%$ lebih tinggi persentasinya dibandingkan siswa yang menjawab salah. Hasil analisis data tersebut dapat disimpulkan bahwa kebanyakan siswa lamban belajar dalam proses penyelesaian masalah (PPM) hanya dapat menjawab beberapa konsep saja yaitu sebesar 33,3\%. Untuk proses mengubah masalah ke kalimat matematika banyak siswa lamban belajar menjawab tidak tepat (TT) dengan 
persentasi sebesar $40 \%$. Sedangkan untuk simbol matematika banyak siswa yang menjawab dengan sedikit kekurangan penulisan jika dilihat dalam bentuk persentasi yaitu sekitar $60 \%$. Analisis data yang diperoleh menunjukkan bahwa komuikasi tulis siswa mengalami kekurangan dalam mengubah masalah kekalimat matematika (MKM) serta dalam perhitungan (PH). Terdapat beberapa faktor yang mempengaruhi komunikasi tulis siswa terganggu, diantaranya banyak siswa siswa yang kurang konsentrasi dalam mengerjakan soal, situasi kelas yang kurang kondusif, serta jam pelajaran yang sudah hampir habis, hal ini mengakibatkan siswa tidak dapat mengerjakan soal dengan benar dan terburu- buru. Dari data diatas dapat disimpulkan bahwa anak lamban belajar memiliki masalah pada komunikasi tulisnya.

\section{Deskripsi Kemampuan Komunikasi Matematis Lisan Siswa Lamban Belajar}

Berikut ini adalah hasil transkip tes lisan siswa lamban belajar pada subjek pertama di SD Negeri 1 Sukamaju dalam menyelesaikan soal matematika yaitu:

$p$ : "ayo nak kita baca bersama-sama lagi soalny, apa perintah pada soal tersebut?"

$j_{1}$ : (membaca soal) "disuruh membuat gambar bu"

$p:$ "gambar bangun apa nak"

$j_{2}:$ "trapesium $A B C D$ "

$p$ : "setelah itu menentukan apa lagi pada soal tersebut?"

$j_{3}$ : "(diam sejenak sambil berpikir) "yang ini bu" (menunjuk pada soal) sisi, sudut, diagonalnya.

$p:$ "selanjutnya apa yang pertama kali kamu kerjakan?"

$j_{4}:$ " eeeeee...... apa ya?" sepertinya membuat gambar ya bu ?"

$p$ : "oke kalau begitu, sekarang ibu mau kamu jelaskan dari gambar yang kamu buat, coba tentukan mana sisi sejajar, sisi sama panjang, dan rumusnya seperti apa?"

$j_{5}:$ "ABCD”

$p:$ "kalau luasnya, sisi-sisinya yang sama panjang nya gimana?"

$j_{6}: " 1 / 2 \times \mathrm{t}$

$p:$ "selanjutnya t itu simbol apa nak?"

j7: "itu tingginya bu:"

p: "kalau simbol sejajar itu bagaimana?"

$j_{8}:$ "(diam menggelengkan kepala)

$p$ : "oke makasih ya nak boleh duduk ke tempatnya"

Dari hasil transkip lisan diperoleh:

a. Siswa mengucapkan hal-hal yang kuarang relevan dalam masalah, terllihat pada kutipan $j_{2}$ dan $j_{3}$.

b. Siswa mengucapkan langkah- langkah tetapi tidak menyelesaikan masalah terlihat pada kutipan $j_{5}, j_{6}$ dan $j 7$.

c. Siswa ragu- ragu ketika menjelaskan penyelesaiian masalah, terlihat pada kutipan $j_{4}$ dan $j_{7}$.

Berdasarkan uraian analisis data di atas dan dikaitkan dengan rubrik tingkat komunikasi tulis dapat disimpulkan bahwa subjek pertama menempati tingkat 2 dengan kategori prosedur samar.

Berikut ini adalah transkip hasil tes lisan siswa lamban belajar pada subjek kedua yaitu sebagai berikut: 
p: "ayo nak kita baca bersama- sama soalnya kembali, apa perintah pada soal tersebut?"

$j_{1}$ : "(diam)... "aduuhhhh apa ya......?" gambar mungkin bu,"

p: "oke good!" selanjutnya gimana gambarnya?"

$j_{2}:$ "(menggambar bangun jajar genjang) "begini buk gambarnya"

$p$ : "ini gambar bangun datar apa nak?"

$j_{3}:$ " trapesium bu"

$p$ : “ ini namanaya bukan trapesium, ini gambar bangun datar jajar genjang, kalau trapesium itu gambarnya seperti ini (sambil membuat gambar trapesium sama kaki), sekarang sudah paham yang mana gambar trapesium dan jajar genjang?"

$j_{4}:$ "iya b u sudah"

Berdasarkan transkip lisan diperoleh:

a. Siswa mengucapkan hal- hal yang tidak relevan dengan masalah terlihat pada kutipan $j_{1}$.

b. Siswa mengucapkan langkah- langkah penyelesaiian yang salah terlihat pada kutipan $j_{2}$ dan $j_{3}$

c. Siswa ragu- ragu ketika menjelaskan terlihat pada kutipan $s_{1}$

Berdasarkan uraian analisis data di atas dan dikaitkan dengan rubrik tingkat komunikasi tulis dapat disimpulkan bahwa subjek kedua menempati tingkat 1 dengan kategori Informasi yang diberikan tidak rinci dan tidak menujukkan proses solusi. Deskripsi hasil komunikasi lisan siswa lamban belajar yang diperoleh dari ketiga butir soal tersebut dapat ditulis kedalam bentuk persentase seperti pada tabel dibawah ini:

Tabel 2. Persentasi Hasil Analisis Kemampuan Komunikasi Lisan Siswa

\begin{tabular}{|c|c|c|c|c|c|c|c|c|c|c|c|c|c|c|c|}
\hline \multicolumn{16}{|c|}{ Kriteria } \\
\hline \multicolumn{5}{|c|}{ MRM (\%) } & \multicolumn{4}{|c|}{ LDP (\%) } & \multicolumn{4}{|c|}{ LP (\%) } & \multicolumn{3}{|c|}{$P(\%)$} \\
\hline B & SK & $\begin{array}{l}\mathrm{SC} \\
\mathrm{M}\end{array}$ & $\mathrm{KR}$ & $\begin{array}{l}\mathrm{T} \\
\mathrm{R}\end{array}$ & B & SK & SM & $\begin{array}{c}\text { TM } \\
\text { M }\end{array}$ & B & SK & $\begin{array}{c}\mathrm{MS} \\
\mathrm{S}\end{array}$ & $S$ & $\begin{array}{l}\mathrm{T} \\
\mathrm{M}\end{array}$ & $\begin{array}{l}\mathrm{A} \\
\mathrm{M}\end{array}$ & M \\
\hline $\begin{array}{l}6, \\
6\end{array}$ & $\begin{array}{c}26, \\
6\end{array}$ & 13,3 & $\begin{array}{c}33 \\
3\end{array}$ & $\begin{array}{l}2 \\
0\end{array}$ & $\begin{array}{c}13 \\
3\end{array}$ & $\begin{array}{l}2 \\
0\end{array}$ & $\begin{array}{c}13 \\
3\end{array}$ & 40 & $\begin{array}{l}6, \\
6\end{array}$ & $\begin{array}{c}26, \\
6\end{array}$ & $\begin{array}{c}26 \\
6\end{array}$ & $\begin{array}{l}4 \\
0\end{array}$ & 6,6 & 40 & $\begin{array}{c}53 \\
3\end{array}$ \\
\hline
\end{tabular}

Berdasarkan Tabel 4, data yang diperoleh dari analisis kemampuan komunikasi lisan siswa untuk proses pengucapan hal yang relevan dengan masalah (MRM) siswa yang menjawab dengan benar (B) hanya sebesar $6,6 \%$ dari indikator pencapaian $60 \%$. Sedangkan persentasi tertinggi dalam (MRM) adalah (KR) yaitu kurang relevan dengan persentasinya sebesar 33,3\%. Dari data tersebut diperoleh bahwa untuk proses pengucapan yang relevan (MRM) banyak siswa lamban belajar yang kurang relevan dalam mengucapkan masalah ini terlihat dari persentasi jawaban siswa yang kurang relevan (KR) lebih tinggi dari pada siswa yang menjawab dengan benar.

Pengerjaan langkah yang diperlukan dalam perhitungan (LDP) siswa yang menjawab dengan benar hanya sebesar $13,3 \%$ dari indikator pencapaian $60 \%$ dan persentasi tersebut sama dengan siswa yang menjawab dengan kriteria (SM) atau sebagian masalah. Sedangkan untuk persentasi tertinggi (LDP) adalah jawaban siswa yang masuk kriteria (TMM) atau tidak menyelesaikan masalah dengan persentasi sebesar $40 \%$. Berdasarkan analisis data diatas dapat disimpulkan bahwa masih banyak jawaban siswa yang masuk kriteria (TMM) atau 
tidak menyelesaikan masalah. Ini terlihat dari persentase TMM lebih besar dari pada persentase siswa yang menjawab benar (B).

Dilihat dari analisis langkah perhitungan (LP) siswa yang menjawab dengan benar hanya sebesar $6,6 \%$ dari indikator pencapian $60 \%$. Sedangkan untuk persentasi siswa yang menjawab dengan sedikit kesalahan (SK) sebesar $26,6 \%$. Untuk siswa yang menjawab salah (S) persentasinya sebesar $40 \%$. Dari analis yang diperoleh terlihat jelas bahwa untuk penyelesaian langkah perhitungan (LP) masih banyak siswa yang menjawab salah hal ini ditunjukan dengan persentase yang lebih besar dibanding persentase siswa yang menjawab dengan benar.

Persentasi siswa dalam memberikan penjelasan terhadap suatu masalah atau ( $P$ ) yang menjawab denagan lancar tanpa ragu- ragu (TM) hanya sebesar $6,6 \%$ dari $60 \%$ indikator pencapaian yang diharapkan. Dari data tersebut diperoleh hasil untuk proses penjelasan terhadap suatu masalah persentasi tertinggi terdapat pada siswa yang menjawab dengan ragu- ragu/ macet (M) yaitu sebesar $53,3 \%$. Oleh karna itu dapat disimpulkan untuk proses penjelasan $(P)$ siswa masih banyak yang ragu- ragu dalam megucapkan hal yang relevan. Ini dapat dilihat dari persentase siswa yang menjawab ragu-ragu lebih besar dari pada persentasi siswa yang menjawab dengan benar.

Berdasarkan hasil analisis persentase data yang diperoleh dapat disimpulkan bahwa untuk pengucapan hal yang relevan dengan masalah atau (MRM) banyak siswa lamban belajar mengucapkan hal yang kurang relevan (KR). Sedangkan untuk penyelesaiain langkah yang di perlukan dalam perhitungan atau (LDP) banyak jawaban siswa lamban belajar yang masuk kategori tidak menyelesaikan masalah atau (TMM). Dilihat dari langkah perhitungan (LP) banyak jawaban siswa yang masih salah ini terlihat dari persentase nya yag lebih besar yaitu sekitar $40 \%$. Persentase tertinggi pada kriteria penjelasan masalah yang terdapat dalam soal, banyak siswa lamban belajar yang masih terlihat ragu- ragu dalam menjelasakan masalah. Hal ini menunjukkan kemapuan komunikasi lisan siswa lamban belajar masih tergolong kurang lancar. Adapun faktor yang mempengaruhi komunikasi lisan siswa diantaranya: siswa lamban belajar memiliki keterbatasan dalam berbicara sehingga sulit menyampaikan ide. Siswa lamban belajar juga memiliki daya tangkap yang kurang sehingga sulit memahami masalah yang diberikan. Selain itu siswa lamban belajar kurang percaya untuk menyampaikan jawaban mereka ini terlihat dari penjelasan mereka yang terkesan ragu- ragu. Hal ini lah yang mengakibatkan komunikais lisan siswa lamban belajar terganggu. Dari data diatas dapat disimpulkan bahwa anak lamban belajar memiliki masalah pada komunikasi lisannya.

Tabel 3. Perbandingan triangulasi teknik dari komunikasi tulis dan lisan

\begin{tabular}{lcc}
\hline \multirow{2}{*}{ Kriteria } & Komunikasi Tulis & Komunikasi Lisan \\
\cline { 2 - 3 } & Jawaban Benar & Jawaban Benar \\
\hline Proses penyelesaian Masalah & $26 \%$ & $6,6 \%$ \\
Langkah Penyelesaian Masalah & $33,3 \%$ & $13,3 \%$ \\
Perhitungan & $6,6 \%$ & $6,6 \%$ \\
\hline
\end{tabular}

Berdasarkan Tabel 5, analisis komunikasi tertulis siswa lamban belajar (slow learner) dari ketiga soal yang diujikan dalam proses penyelesaian masalah siswa yang menjawab 
dengan benar dari keseluruhan subjek tersebut mencapai $26 \%$. Sedangakan perbandingan dengan siswa yang menjawab benar pada komunikasi lisan hanya mencapai 6,6\%. Dilihat dari kriteria langkah penyelesaian masalah untuk komunikasi tertulis siswa yang menjawab benar sebesar 33,3\% sedangkan untuk langkah penyelesaian masalah pada komunikasi lisan siswa lamban belajar hanya menjawab sebesar $13,3 \%$. Hal ini berbeda dengan kriteria perhitungan, untuk jawaban siswa yang menjawab benar pada komunikasi tulis sama dengan siswa yang menjawab benar pada komunikasi lisan yaitu mencapai $6,6 \%$.

Berdasarkan hasil perbandingan triangulasi diatas dapat disimpulkan bahwa siswa lamban belajar (Slow learner) komunikasi tertulisnya lebih baik dari pada komunikasi lisan. Hal ini terbukti dari hasil perbandingan siswa yang menjawab benar pada komunikasi tertulis jauh lebih besar dibandingkan jawaban benar pada komunikasi lisan.

Siswa lamban belajar mengalami masalah pada komunikasi lisan dan komunikasi tulis. Untuk mengetahui komunikasi tulis siswa lamban belajar penulis menggunakan beberapa tes. Hasil yang diperoleh terlihat bahwa siswa lamban belajar mengalami kesulitan dalam proses penyelesaian masalah ini terbukti dari banyaknya jawaban siswa yang menjawab tidak tepat. Selain itu dilihat dari cara siswa mengubah masalah kedalam kalimat matematika banyak siswa yang tidak bisa mengubah ke dalam kalimat matematika sehingga siswa kesulitan dalam mengerjakan soal yang diberikan.

Dilihat dari proses perhitungan siswa lamban belajar banyak kesalahan dalam menyelesaikan soal yang berhubungan dengan perhitungan. Untuk penulisan simbol matematika siswa lamban belajar banyak yang kurang tepat dalam menuliskan simbol matematika. Selain itu siswa lamban belajar membutuhkan waktu yang sangat lama untuk menyelesaikan soal sehingga perlu bantuan penulis untuk membimbing siswa lamban belajar tersebut sehinga siswa paham maksud dari soal tersebut.

Sedangkan untuk mengetahui kemampuan komunikasi lisan siswa lamban belajar penulis menggunakan wawancara. Hal-hal yang ditanyakan dalam proses wawancara yaitu berkaitan dengan bagaimana siswa mengucapkan hal-hal yang relevan dengan masalah, langkah-langkah yang diperlukan dalam perhitungan, bagaimana langkah pengerjaan soal siswa lamban belajar serta bagaimana penjelasan siswa dalam mengucapkan masalah apakah terkesan ragu- ragu atau sebaliknya.

Berdasarkan hasil wawancara dengan siswa lamban belajar diketahui bahwa siswa lamban belajar dalam mengucapkan masalah banyak siswa yang memberikan penjelasan yang kurang relevan. Untuk langkah-langkah yang diperlukan dalam perhitungan, banyak dari siswa lamban belajar mengucapkan hal-hal yang tidak dapat menyelesaikan masalah . Sedangkan untuk langkah pengerjaan soal banyak siswa yang mengucapkan langkahlangkah pengerjaan soal yang salah. Selain itu untuk proses penjelasan banyak siswa yang menjawab dengan ragu- ragu atau macet. Sehingga perlu bantuan peneliti untuk memberikan keyakinan kepada siswa tersebut bahwa jawaban mereka adalah yang terbaik. Tidak hanya itu penulis juga perlu memberikan penjelasan berulangkali karna daya tangkap siswa sangat lambat sehingga mudah lupa.

Dilihat dari analisis jawaban siswa tersebut baik menggunakan tes maupun wawancara penulis menyimpulkan bahwa siswa lamban belajar memiliki masalah dari segi komunikasi baik komunikasi tulis maupun komunikasi lisan. Akan tetapi jika dibandingkan antara keduanya yaitu antara komunikasi tulis dan komunikasi lisan siswa yang lebih baik yaitu 
komunikasi tulis siswa hal ini dikarnakan siswa yang menjawab benar jauh lebih banyak dibandingkan jawaban siswa yang menjawab benar pada komunikasi lisan.

Faktor yang mempengaruhi komunikasi tulis siswa jauh lebih baik dibandingkan kan komunikasi lisan dikarnakan waktu yang dibutuhkan siswa dalam mengerjakan soal jauh lebih lama dibandingkan pada saat wawancara. Selain itu siswa lamban belajar mengalami kesulitan dalam mengungkapkan ide secara lisan dikarnakan siswa lamban belajar memiliki keterbatasan dalam berbicara, sehingga dalam komunikasi lisan banyak siswa lamban belajar yang tidak dapat mengucapkan hal-hal yang relevan dengan masalah mereka cenderung hanya diam atau tersenyum ketika peneliti memberikan pertanyaan, hal ini yang mempengaruhi komunikasi lisan siswa jauh lebih rendah dari pada komunikasi tulis siswa.

\section{SIMPULAN DAN SARAN}

Berdasarkan hasil penelitian dan pembahasan yang telah dijelaskan sebelumnya, maka diperoleh kesimpulan sebagai berikut:

1. Komunikasi tulis siswa lamban belajar jauh lebih baik dibandingkan komunikasi lisan siswa, hal ini dikarnakan jawaban siswa yang menjawab benar jauh lebih banyak dibandingkan jawaban siswa yang menjawab benar pada komunikasi lisan. Komunikasi matematika tulis siswa lamban belajar dalam proses penyelesaian masalah membutuhkan waktu yang sangat lama dalam menyelesaikan soal tersebut. Sehingga kemampuan subjek dalam memecahkan masalah masih perlu bantuan penulis.

2. Siswa lamban belajar dalam komunikasi lisan memiliki keterbatasan untuk berbicara mereka lebih banyak diam atau bahkan hanya tersenyum. Selain itu informasi yang disampaikan penulis kurang bisa dipahami oleh siswa lamban belajar sehingga mereka kesulitan mengungkapkan ide. Hal ini yang membuat komunikasi lisan siswa lebih rendah dibandingkan komunikasi tulis siswa lamban belajar.

\section{DAFTAR PUSRAKA}

Sisdiknas. (2010). Sistem Pendidikan Nasional. Jakarta: Sinar Grafika.

Sugiono. (2009). Metode Penelitian Pendidikan Pendekatan Kualitatif, Kuantitatif, dan R\&D. . Bandung: Alfabeta.

Supriadi, N. (2017). Pembelajaran Geometri Berbasis Geogebra Sebagai Upaya Meningkatkan Kemampuan Komunikasi Matematis Siswa Madrasah Tsanawiyah (MTs). Al-Jabar: Jurnal Pendidikan Matematika, 1-14.

Triani, N. (2013). Pendidikan Anak Berkebutuhan Kusus Lamban Belajar Slow Learner. Jakarta Timur: PT: Luxima Metro Media. 